\title{
RESENHA
}

\section{MEISTER ECKHART EM PORTUGUÊS: O PRIMEIRO VOLUME DOS SERMÕES ALEMÃES}

MESTRE ECKHART. Sermões alemães: sermões 1 a 60. Tradução de Enio Paulo Giachini. Petrópolis/Bragança Paulista: Vozes/Editora Universitária São Francisco, 2006. 366p. v. 1.

Rodrigo Guerizoli* rguerizoli@ufrj.br

Basta reparar que o pequeno volume $O$ livro da divina consolação $e$ outros textos seletos, editado em 1991, com tratados e sermões de Mestre Eckhart, encontra-se atualmente em sua sexta edição para que se perceba o quão bem-vinda é a tradução que ora se publica e que se apresenta como o primeiro passo de um projeto que "prevê a tradução e publicação, inicialmente, das obras alemãs completas e, posteriormente, também das obras latinas" (p. 36) do dominicano turíngio. O volume reúne os 60 primeiros sermões da edição crítica de Stuttgart das obras de Eckhart, contando, ainda, com uma breve apresentação, de autoria de Emmanuel C. Leão, uma introdução, assinada pelo tradutor e que agrupa informações biográficas, editoriais e um conjunto de "temas do pensamento do mestre" (p. 20); e, por fim, com um "glossário comentado" de termos-chave do pensamento eckhartiano.

Eckhart é, sem dúvida, um autor multifacetado, constantemente em movimento, tendo atuado em diferentes cidades (Erfurt, Paris, Estrasburgo, Colônia) e produzido tanto em latim quanto em vernáculo. Esse dinamismo, ao

* Professor do Departamento de Filosofia da Universidade Federal do Rio de Janeiro (UFRJ).

KRITERION, Belo Horizonte, nº 115, Jun/2007, p. 273-276 . 
mesmo tempo geográfico e lingüístico, reflete-se numa obra que trafega por diversos mundos e línguas, o que contribui para que se tome seu autor como um contra-exemplo da assim chamada imobilidade do mundo latino, como um outsider do intelectualismo medieval, que escolhe uma língua que não é a oficial e que representa um modo de pensar que mal se encaixa num tempo de grandes sínteses filosóficas e teológicas. Desde esse ponto de vista, e em prol da originalidade e do elogio, sistematicidade e inserção histórica perdem em valor frente à exceção e à intemporalidade de um gênio que vive num período em decadência. Essa é a chave de leitura que guia a apresentação da presente tradução, em que Eckhart aparece como "o João Batista da parúsia moderna de Cristo" (p. 11), surgido num momento que começa a, de forma irreversível, "perder substância histórica" (p. 9). Trata-se, portanto, de uma via de acesso que tende a sublinhar a importância e a novidade da obra alemã de Eckhart e a distância deste em relação às estruturas hegemônicas de sua época; numa palavra, sua excentricidade. Essa perspectiva, porém, historicamente hegemônica até pelo menos a redescoberta, em fins do século XIX, da obra latina de Eckhart, tem encontrado cada vez menos espaço no âmbito da atual recepção do pensamento eckhartiano. Neste predomina, ao contrário, uma leitura que busca, de maneira cada vez mais nítida, inserir Eckhart em seu contexto, ou seja, no mundo intelectual medieval, um mundo com suas referências próprias (Aristóteles, Alberto Magno, Avicena, Tomás de Aquino etc., todos citados, nominalmente ou não, com freqüência, por Eckhart), escolástico sim, mas nem por isso filosoficamente paralisado, e no qual começa a ganhar força o que veio a se chamar de "desprofessionalização" da filosofia medieval, um movimento que é representado menos pelo surgimento ab ovo de uma filosofia vernácula do que pelo esforço de uma nova translatio studiorum, feita agora não para, mas, antes, desde o latim. ${ }^{1}$

A biografia de Eckhart, tal como a de inúmeros autores medievais, nos é bastante lacunar. Diversas etapas de sua formação e desenvolvimento intelectual podem ser apenas inferidas dos poucos dados de que dispomos. Nesse sentido, é sempre arriscado apresentar, como se faz na apresentação e na introdução da presente edição, um grande número de datas que pretendem registrar os marcos de uma vida. As falhas são, nesse contexto, inevitáveis. Por exemplo. ${ }^{2}$

1 Um excelente panorama das tendências que têm orientado as investigações sobre Eckhart fornecem SPEER, Andreas; WEGENER, Lydia (Org.). Meister Eckhart in Erfurt. Berlin/New York: Walter de Gruyter, 2005. Sobre a "desprofissionalização" da filosofia medieval cf., sobretudo,: DE LIBERA, Alain. Pensar na Idade Média. São Paulo: Editora 34, 1999.

2 A corrigir há, sem mais, o lapso que indica 1275 como o ano do óbito de Tomás de Aquino (p. 11). 
1) Informações conflitantes são apresentadas acerca da docência de Eckhart em Colônia: num momento, é "desde 1322" que Eckhart "ensina teologia no Studium Generale de Colônia" (p. 12); noutro, "foi em 1323 que o geral da Ordem enviou-o para Colônia" (p. 17).

2) Eckhart é apresentado como tendo nascido "numa das duas cidades da Turíngia com o nome de Hochheim" (p. 11 e p. 15), quando, com base numa detalhada história regional, é hoje amplamente aceito que, no caso em questão, Hochheim não é topônimo, mas sobrenome de família, e que Eckhart teria nascido em Tambach, ao sul de Gotha, na mesma região. ${ }^{3}$

3) Não há registro confiável sobre eventos ligados à estada de Eckhart em Avignon. Assim, mais prudente é admitir, como o faz por exemplo K. Ruh, ${ }^{4}$ nossa ignorância a esse respeito, do que especular, quiçá a partir de obras de questionável fidedignidade, acerca da causa mortis de Eckhart (p. 19) ou sobre o local de seu sepultamento (idem).

4) O estopim para a instauração do processo contra Eckhart proveio de uma denúncia feita por, pelo menos, dois de seus confrades: Hermann de Summo e Guilherme de Nidecke ${ }^{5}$. Na base do processo, parece estar, portanto, uma divisão na própria ordem dominicana, ligada provavelmente a questões disciplinares, e não diretamente à inveja do Arcebispo de Colônia frente à "prosperidade intelectual e mesmo material, sua [de Eckhart] e da ordem dos pregadores" (p. 17).

5) Estudos recentes refutam a tese, por muito tempo aceita, de que "os sermões e tratados alemães jamais foram reunidos como 'livros', e nem sequer eram subscritos por Eckhart” (p. 35). Ao contrário, temos hoje por certo que a participação de Eckhart na confecção do que nos foi transmitido é relevante, tendo-se mesmo por provável a existência de um exemplar pessoal de seus textos. ${ }^{6}$

Nem tais incorreções, no entanto, tampouco a escolha de um viés interpretativo marcado pela contingência de por séculos ter-se conhecido apenas a obra alemã de Eckhart, põem em xeque a qualidade da tradução que ora se apresenta. O texto proposto por Enio Paulo Giachini é fluente, elegante, se

6 Cf. LÖSER, Freimut. Einzelpredigt und Gesamtwerk. Autor- und Redaktortext bei Meister Eckhart. Editio, Tübingen, v. 6, p. 43-63, 1992; STURLESE, Loris. Hat es ein Corpus der deutschen Predigten Meister Eckhart gegeben? Liturgische Beobachtung zu aktuellen philosophiehistorischen Fragen. In: SPEER; WEGENER, op. cit., p. 393-408. 
baseia na edição de referência das obras de Eckhart e consegue encontrar amiúde excelentes soluções para difíceis passagens do original. Um fato que se deve vivamente ressaltar consiste no esforço do tradutor em se pautar nos momentos mais complexos de sua tarefa diretamente no texto médio-alto-alemão (indicado nesses casos em nota junto à tradução de Josef Quint) para a elaboração de sua solução (p.ex.: p. 72, p. 98 e p. 143), a qual, justificadamente, distancia-se amiúde do texto proposto por Quint em favor de uma formulação mais interessante e mais atenta ao original. Numa palavra, trata-se de uma tradução de valor, que não se perde na às vezes profundamente imbricada sintaxe eckhartiana e que, em regra, consegue transpor, para um português apurado, as mais rebuscadas tournures da língua do Mestre turíngio.

Como sói inevitavelmente ocorrer em primeiras edições, certos deslizes de revisão (p.ex.: p. 16, p. 199, p. 220 e p. 281) se fazem presentes. Nos limites dessa resenha, restrinjo-me a dois pontos que considero exigirem uma correção mais urgente, mas que de modo algum colocam em xeque o saldo plenamente positivo da presente tradução:

1) O termo grunt é geralmente traduzido como fundo (p. ex.: p. 67, p. 108, p. 119 e p. 126). Todavia, no sermão 2 (p. 48) a opção é por abismo (p. 48). Fundo é, porém, uma tradução mais feliz, pois abismo é exigido como tradução de abgrunt (p. 102).

2) Os termos mente e intelecto são usados de modo inconstante como tradução tanto de vernünfticheit quanto de vernunft (p.ex.: p. 52, p. 82, p. 144, p. 158, p. 174 e p. 217). Uma vez que mente sugere que o original remeta ao mens latino e não ao intellectus, uma tradução constante de vernünfticheit e vernunft por intelecto, dada a sobreposição de sentidos em que Eckhart usa tais termos, seria mais esclarecedora.

Como já indicado, a obra termina por um "glossário comentado" que não se apresenta como um dicionário filosófico-filológico do vocabulário eckhartiano - o que certamente seria de bastante proveito -, mas, antes, como um conjunto de indicações que buscam "começar a despertar o gosto e o interesse de ler e entender os textos de Eckhart" (p. 327). Oxalá consiga esse "convide à reflexão" (idem) atingir seu intuito e que se venha, como a presente tradução, contribuir para a consolidação em nossas universidades de um interesse filosófico sobre a obra de Mestre Eckhart. 